\title{
Effect of Gas Flaring on Soil and Cassava Productivity in Ebedei, Ukwuani Local Government Area, Delta State, Nigeria
}

\author{
Morrison Ifeanyi Atuma ${ }^{1}$, Vincent Nduka Ojeh ${ }^{2}$ \\ ${ }^{1}$ Department of Arts \& Humanities, School of General Studies, Delta State Polytechnic, Ogwashi-Uku, Nigeria; ${ }^{2}$ Graduate Research \\ Programme, West African Science Service Center on Climate Change and Adapted Land Use (WASCAL), Federal University of \\ Technology, Akure, Nigeria. \\ Email: morrisonatus@yahoo.com,drojehvn@hotmail.com
}

Received December $30^{\text {th }}, 2012$; revised February $2^{\text {nd }}, 2013$; accepted March $5^{\text {th }}, 2013$

Copyright (C) 2013 Morrison Ifeanyi Atuma, Vincent Nduka Ojeh. This is an open access article distributed under the Creative Commons Attribution License, which permits unrestricted use, distribution, and reproduction in any medium, provided the original work is properly cited.

\begin{abstract}
The threat to human, fauna and flora life posed by pollution due to gas flaring cannot be over-emphasized. Gas flared often resulted in some environmental degradation, one of such influence is soil pollution and poor crop yield. This study examined the effect of gas flaring on soil and cassava productivity in Ebedei, Ukwuani LGA, Delta State. For the purpose of data collection, five (5) experimental sites were systematically selected around the flare site in Ebedei and a control site at Obiaruku. Soil samples were collected at surface $0-10 \mathrm{~cm}$ and $10-20 \mathrm{~cm}$ at distance of $50 \mathrm{~m}, 100 \mathrm{~m}, 150$ $\mathrm{m}, 200 \mathrm{~m}$ and $250 \mathrm{~m}$ apart respectively away from the bund wall of the flare. The data generated were analysed using multiple regression and paired t-test analyses. The study revealed that the soils found in Ebedei have high composition of sand and soil temperature and are acidic. The soil electrical conductivity, Phosphorous, Nitrogen, Potassium and Sodium were very low. More so, the yield of cassava increases with a corresponding increase in distances from flare site. The first hypothesis revealed that there is significant variation in soil nutrients as distance increases from gas flare sites. This is evident from $\mathrm{F}$ value of 234.99 which is greater than the critical table value of 4.39 . Furthermore, as flare distance increases, so also the organic carbon, electrical conductivity and Nitrogen increase. The second hypothesis revealed that there is a significant difference in cassava yield at gas-flared area and the non-flared area which is evident at $\mathrm{t}$ (6.032) is greater than the critical table (1.895) at $\mathrm{P}<0.05$. It is therefore recommended that Government and FEPA should enact environmental Policies and revisit and review existing environmental and oil drilling laws in Nigeria with a view of updating them to international and environmental friendly standards.
\end{abstract}

Keywords: Gas Flaring; Soil; Cassava Productivity; Ebedei

\section{Introduction}

The threat to human, animals and plants life posed by pollution due to gas flaring cannot be over-emphasized [1]. The impact of gas flaring is of local and global concern [2]. Gas flaring is the unscientific burning of excess hydrocarbons gathered in an oil/gas production flow station/site. The burning of such gases releases huge volumes of greenhouse gases to the atmosphere, while emitted sulphur dioxide returns to the soil as acid rain [3]. Associated natural gas is a by-product of oil extraction process and is often considered more of a nuisance than an economic resource [4]. The main components of this flared gases include carbon (iv) oxide $\left(\mathrm{CO}_{2}\right)$, methane
$\left(\mathrm{CH}_{4}\right)$, nitrous oxide $\left(\mathrm{NO}_{2}\right)$, water vapour and sulphur dioxide $\left(\mathrm{SO}_{2}\right)$.

A gas flare or flare stack is an elevated vertical or horizontal stack found on oil wells or oil rigs and in refineries, chemical plants and landfills used for burning off unwanted gas or flammable gas and liquids released by pressure relief values during over-pressuring of plant equipment [5]. It is a well-known fact that Nigerian oil reserves contain high amount of gas. During the process of oil drilling the gas is constantly being released and one of the ways to get rid of it is by setting fire to it and burning it off using a process called gas flaring. In this process so many by-products of combustion are released into the atmosphere. 
Gas flaring is a common practice in the oil production process that is not restricted to Nigeria only. Libya for instance flares about $21 \%$ of its natural gas, while Saudi Arabia, Canada and Algeria flare $20 \%, 8 \%$ and $5 \%$, respectively [6]. In 2002, Nigeria flared about $76 \%$ of its natural gas [6] and about $60 \%$ in 2006 [7]. The flared gas has a lot of environmental implications. For instance, gas flaring is observed to reduce atmospheric quality through the release of pollutants like carbon (c), nitrogen dioxide $\left(\mathrm{NO}_{2}\right)$ sulphur dioxide $\left(\mathrm{SO}_{2}\right)$ and lead $(\mathrm{Pb})$ among others into the atmosphere [8-10]. Gas flaring is also reported to cause acid rain within the flare's microenvironment [11].

More gas is flared in Nigeria than anywhere else in the world. Estimates are highly unreliable, but roughly 2.5 billion cubic feet of gas associated with crude oil is wasted in this way every day. This is equal to $40 \%$ of all Africans natural gas consumption in 2001, while the annual financial loss to Nigeria is about US $\$ 2.5$ billion [12]. It is important, to state here that gas flaring has been the subject of much controversy in Nigeria, due to its wasteful nature and negative impact on the environment and it contributes significantly to destroying the soil [13].

However, soils found in the Niger-Delta area are one of the worst soils as a result of the environmental pollution by the oil industry in the region [14]. Soil is one of the basic components that support life and productivity in the ecosystem. Moreso, the flora, fauna and man depend on soil for support and effective functioning. Oil production involves the release of materials and substances that are poisonous and have detrimental impact on the environment. In Ebedei, gas flaring is the major source of thermal pollution which occur $24 \mathrm{hrs}$ every day, for some years ago and this affects agricultural potentials, other related activities in Ebedei and environs. According to Alakpodia [15], thermal pollution causes a distinct micro-climate around the vicinity of operation. This can be seen from the magnitude of the havoc done by gas flaring to forest and mangrove of Niger Delta which is beyond description [16].

Every year, the oil industry burns off up to 170 billion cubic meters of natural gas released from the oil extraction process [17]. The practice, known as gas flaring, not only harms the environment by emitting some 400 million tons of carbon dioxide globally, but also a wasteful of cleaner energy source. In Africa alone 40 billion cubic meters of gas are burnt every year, which if put into use could generate half of the electricity needed in the continent [18].

It is a fact that about $70 \%$ of the total volume of associated gases produced are constantly flared, which affect our living environment, especially those communities that are situated closely to gas flaring sites [19]. The production of oil, discovered in the Niger Delta 40 years ago, is having a devastating effect on Nigeria's largest wetland region. More gas is flared in Nigeria, than anywhere else in the world [20]. The mixture of toxic substances, which have been emitted in the flares for over 40 years, including benzene particles, have exposed Niger Delta communities to severe health risks and severe damages [21,22].

Currently, there are more than 100 gas flaring sites, some of which burn ceaselessly for 50 years and contribute to increased greenhouse gases emission [23]. Thus, resulting to climate change, the impact of which are already being felt in the region with food insecurity, increasing risk of disease and the rising costs of extreme weather damage. These gases flared contain toxins, such as benzene, which pollute the air and dangerous to human health resulting to diseases such as asthma and bronchitis.

Gas flaring has affects soils found within gas flare areas $[24,25]$. Ebedei is not left out most soils found in the region tends not to support plant growth and as such they are not fertile. Since soil fertility comprises of the presence of Nitrogen, phosphorous and potassium in the soil and other nutrient elements, the presence of gas flare results to increase soil acidity [26].

It is on this basis that the following questions come to mind as: what is the effect of gas flaring on the soil nutrient of Ebedei? Does gas flaring affect cassava yield? What are the gases flared in Ebedei flare site? This study is therefore set to examine the effect of gas flaring on soil and cassava yield in Ebedei community in Ukwuani Local Government Area, Delta State, Nigeria, so as to provide necessary answers to the questions raised.

\section{Literature and Theoretical Framework}

Gas flaring has been reported by many researchers to be a major cause of low agricultural productivity, fishing and hunting in the Niger Delta, thereby impoverishing the inhabitants [27-30]. A critical look at these studies on gas flaring and agricultural productivity shows that they are not scientifically in-depth studies of the impact of gas flaring and crops production; rather they were based on the opinions solicited from respondents by mere use of questionnaires. The few scientific studies include those of Udoinyang [31] and Akpabio [32], on the impact of gas flaring on sweet potato and plantain yield, respectively. They showed that gas flaring reduced the production of these crops within $1 \mathrm{~km}$ of the flare sites. Yam and cassava production is not economically viable within $2 \mathrm{~km}$ radius of the flare site [30]. In this section, the relevant literatures were reviewed on gas flaring and the environment using the various subheadings as follows: gas flaring in Nigeria, gas flaring and soil; gas flaring and agriculture. 


\subsection{Gas Flaring in Nigeria}

The Nigeria oilfield in the Niger-Delta area produce about two million barrels of oil and most of this oil comes from reservoirs containing gas, which is produced with the oil [33]. This associated gas, a by-product of the country's lifeline petroleum exploration activities is separated from the oil at flow station and more than $95 \%$ of it is flared (see Figure 1). Currently are total sum of two billion Standard Cubic Feet per day (SCF/day), which is estimated to be about a quarter of the world gas flares [34].

The main components of this flared include carbon (iv) oxide $\left(\mathrm{CO}_{2}\right)$, methane $\left(\mathrm{CH}_{4}\right)$, nitrous oxide $\left(\mathrm{NO}_{2}\right)$, water vapour and sulphur dioxide $\left(\mathrm{SO}_{2}\right)$. It is estimated that the Nigerian gas flared has released 35 million tons of carbon dioxide and 12 million tons of methane in a year. The low combustion efficiency of Nigerian flare stack $(60 \%-80 \%)$ results in a large portion of the gas emitted being methane and since methane has a higher global warming potential (64 against 1 for $\mathrm{CO}_{2}$ ) [35].

The Nigerian oil industry probably contributes more than any other company of these serious global commons environmental problems. As carbon dioxide and methane are the main greenhouse effect and consequently, this phenomenon has been confirmed to raise the average global temperature by about $0.5^{\circ} \mathrm{C}$ within the last century $[36,37]$. The flaring stations in the Niger-Delta area has been blamed for smoke and flames that damage the air and soil quality in the ecologically fragile delta and contribute to the global greenhouse gases.

The gas flaring in Nigeria have for years been criticized by environmental groups as the world's largest sources of global warming pollutants this acts, which experts attributes to the rise in sea level. In Nigeria however, environmental policies and regulations can be con-

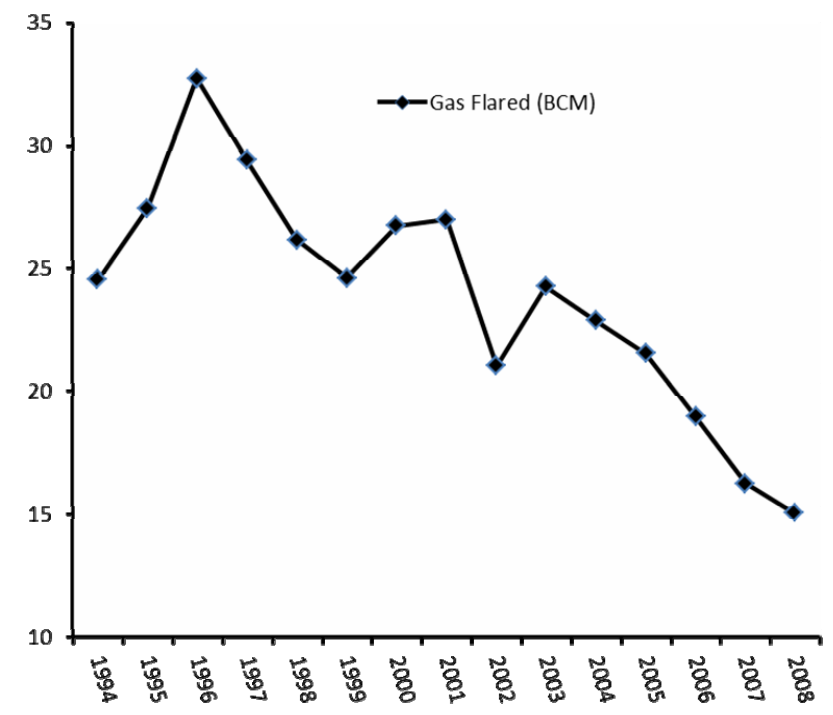

Figure 1. Trend of gas flared in billion cubic metre in Nigeria from 1994-2008. veniently characterized as minimal and poor, as the $\mathrm{Ni}$ gerian government puts profits ahead of the environment and the welfare of its citizens. Nigeria, which according to UN economic commission for Africa is categorized as a gas - surplus country, still has limited associated gas sales as $68 \%$ of the gas is flared and as a result has been associated with climate change and related warming, deforestation and acid rain with attendant impact on agriculture and other physical infrastructure [34].

Heat and noxious gases may contribute to environmental health problem in the Niger-Delta region. Also, there has been timely warming and an increasing global awareness on the need to protect our environment and improve our economy. Typical gas flare in Nigerian oil field are located at ground level and surrounded by thick vegetation, farmland and villages huts $20-30 \mathrm{~m}$ from the flare [2]. Thus, the heat radiation is a function of the flare temperature, gas flow rate and geometrical design of flare stack. There is a great physiological impact on crops planted in the vicinity of the gas flare. The soil mantle of the earth is indispensable for the maintenance of the plant life, affording mechanical support and supplying nutrient and water [2].

Nigeria has a gas reserve, which is over 10 billion standard cubic feet $(\mathrm{bcm})$, and it is found in underground rock reserved with crude oil [24]. Most of the oil in the country (Nigeria) comes from reservoir containing natural gas, which is produced with the oil. On the average, about one thousand standard cubic feet of gas is produced in Nigeria along with each barrel of oil. Invariably some billion standard cubic feet of gas are produced daily [15].

Ogbonnaya [38] posited that huge deposits of gas are associated with crude oil in the oil deposits of Nigeria, while an estimated one trillion cubic metres of natural gas also occur with oil deposits. This implies that about $75 \%$ to $80 \%$ of the gas in Nigeria is flared. The conesquence of this flaring is the emission of about 35 million tons per year of carbon dioxide $\left(\mathrm{CO}_{2}\right)$, methane gas and other associated gasses [17].

World Bank reported that in 1994, the total emission of $\mathrm{CO}_{2}$ from gas flaring in the Niger Delta amounted to an associated 35 million tons per year [17]. Also in October 2, 1991, the daily times news-paper reported that in 1990, Nigeria flared 21.8 billion cubic metres $(\mathrm{Bcm})$ of natural gas, representing $79 \%$ of the $27.5 \mathrm{bcm}$ of gas released by eleven oil producing companies in crude oil exploitation for that year, $8.1 \%$ or $2.24 \mathrm{Bcm}$ was re-injected. According to Central Bank of Nigeria [39], the quantity of gas flared rose from 7957 million cubic metres in 1970 to 22,214 million cubic metres in 1980 and 25,760 million cubic metres in 1990 . These figures show that about $70 \%-92 \%$ of the Nigeria gas is flared.

According to Linden and Moffat [40], they observed 
that as a by-product of oil production, Nigeria flares more gas than any other country in the world, most of it is from the Niger Delta area. These gases combine with the water vapour in the air, falls as acid rain, which affects the soil, vegetation, fishes and man negatively. According to World Bank [17], $87 \%$ of all associated gas is flared by shell and her, cohorts as compared to $21 \%$ in Libya and $0.6 \%$ in United State (see Table 1). In the same vein, Hunt [41] noted that SHELL admits that two billion standard cubic feet of gas a day in the Niger Delta area burnt off. Thus, Nigeria is one of the world's largest single contributors to global warming [5]. However, World Bank records highlighted the fact that the Niger Delta atmosphere receives 80 billion cubic feet of gas from the oil industry through flaring activities $[42,43]$. This is enough to spell doom and disastrous consequences on the people of Niger Delta, their soil, water, vegetation, air and health.

Egbuna [44], noted that in 1986 the total gas flared from over 300 fields in Nigeria yielded a wasted heat equivalent of about $60 \times 10^{9} \mathrm{kwh}$, which is approximately equal to all of the total Electric Power (PHCN) that year from all sources. Egbuna [44], further explain that it is important and relevant to understand the nature of the principal material being handled in natural gas operations. This will help to appreciate fully the "hazard" emanating from them and their impacts on the environment. According to Egbuna [44] "Natural gas" is a mixture of hydrocarbon (containing mainly methane, ethane, propane and butane as well as sometimes their stable chemical derivatives such as ethylene and butylenes), which occur in gaseous state at room temperature and pressure.

\subsection{Gas Flaring and Soil}

The impact of gas flaring on soil is obvious, especially when considered on the basis of the long duration of the flaring. Exchangeable cations are one of the most important chemical bases of soil fertility; deficiencies of these mineral elements are responsible for poor nature of tropi-

Table 1. Percentage of gas flaring in the world.

\begin{tabular}{cc}
\hline Country & \% Flared \\
\hline Nigeria & 76 \\
Libya & 21 \\
Saudi Arabia & 20 \\
Iran & 19 \\
Russia & 11.5 \\
Algeria & 6.8 \\
Mexico & 5 \\
Venezuela & 4.5 \\
Indonesia & 4.5 \\
Britain & 4.3 \\
Egypt & 0.9 \\
U.S.A & 0.6 \\
Netherlands & 0 \\
\hline
\end{tabular}

Source: World Bank [17]. cal soil. However, the cation exchange capacity (CEC) of the soils under gas flaring is very low and reduces the fertility and nutrients of the soil.

The results of studies carried out by Alakpodia [27] and Ogidiolu [45] showed that exchangeable cation or base $\left(\mathrm{Ca} ; \mathrm{Mg}^{\prime}, \mathrm{K}^{\prime}\right.$ and $\left.\mathrm{Na}^{\prime}\right)$ in soils under gas flaring is low. According to their studies, the mean exchangeable cation/base value of the soils under gas flaring is far below the values of 20 milliequivalent $/ 100 \mathrm{~g}$ of soils which, Young [46] observed as required for high soil fertility. The mean value is also lower than 4.0 milliequivalent/100g of soils, which Sanchez [47] suggested for retaining most nutrient cations in the soil. Thus, soils within the 100 metre radius of the site of gas flaring are mostly affected because their nutrient levels are very low. Therefore, no meaningful human activity can be carried out within the area due to excessive heat. They noted also that the low mean value of exchangeable base indicates that gas flaring is detrimental to the accumulation of these basic mineral nutrients in soils and thereby promoting soil fertility loss.

However, Ogidiolu [45] observed that organic matter and total nitrogen decline in gas flaring sites. It also exhibits increasing pattern with increasing distance from the flares. According to him, this decline is brought about by intense heat, which affects the process of the formation of organic matter and total nitrogen formation. Alakpodia [27] in his work soil characteristics under Gas Flares in Niger Delta, Southern Nigeria observed that there is very low mean value of organic matter $(1.83 \%)$ and total nitrogen $(0.08 \%)$ of soils under gas flaring. According to him, heat affects the process of organic matter and total nitrogen formation. Gas flaring activities of the oil companies result in soil acidity with mean $\mathrm{pH}$ values between 4.3 and 5.8 [27,45]. Ogidiolu noted that one major effect of gas flaring on the chemistry of the soil is the increase in acidity. That gas flaring leads to increase in soil acidity means that, it renders soils unproductive agriculturally, because solubility and hence the uptake of nutrients from soil is reduced [45].

Achebe and Epstein [42] asserted that one of the major causes of "rural flight" to urban areas is the pollution of the soil and land (soil depletion). While the concomitant progressive reduction in crop yields in the Niger Delta is another factor. The oil industry has caused soil and land degradation through multiple mechanisms. They said that soil pollution has led to a decline of soil fertility through dumping and building up of toxic substances. There has been a deterioration of the physical properties of soil as a result of reduced organic matter (the structure aeration and water holding capacity of soil), soil chemical properties and reduction of soil organisms, as a result of much heat and associated gases from gas flaring. Abiodun [43] noted also that the environment of the oil bearing region 
has borne to gas flaring. Thus, the valuable wetlands of the Niger Delta in which oil prospecting and production take place have been virtually destroyed.

\subsection{Theoretical Framework}

The theory of Environmental Externality: Environmental Externality is the theoretical framework on which this work is based. Environmental Externalities are damages or benefits which are not paid for by the polluter or beneficiary under normal market condition [48]. Externalities are defined as the costs or benefits which arise when the social economic activities or production system of one group of people have a positive or negative impact on another and in which the first group may fail to fully account for their impact [49].

It is very obvious that every economic activity or production of man on the environment, including soil and gas prospecting and production, has detrimental effects or externalities on the ecosystem. In effect, every productive enterprise generates externalities/damages to others in the course of their production [50]. Environmental externality theory is pioneered by Pigou in his seminal work $[51,52]$. The concept of externality has been well established in the theory of economics. However, it is only since the 1960 s that environmental externalities have received a lot of attention, both in terms of quantification and actions to internalize them.

The theory of externalities demonstrate the need for a set of Pigouvian taxes (subsides) on the generators of an externality or damage to induce them to take proper account of the full range of social costs that their activities entail [53]. Adopting the framework of a market economy and perfect competition, Pigou established that when there are externalities, private and social cost are not equated, nor are private and social benefit equal [52]. Thus, the social cost which damages are born by the receptors of production activities are not equal with that which the polluter bears. Environmental impacts of gas flaring are clearly externalities since they are perfect examples of circumstances where the damages are not fully reflected in potential or actual market exchanges. These externalities are caused by market failures resulting from incomplete markets [54].

Government failure arises from the implementation of erroneous policies, ignorance and incomplete information [52]. Both market failure and government failure have resulted and is till resulting in an excessive use of environmental resources, which leads to environmental degradation.

However it is important to understand here that the externality costs or negative externalities will be considered in the study. External cost or negative externality is any loss of human wellbeing associated with a process that is not already allowed in its price [48]. A good example is the gas flaring pollution, which the benefit oriented production of the oil companies produces detrimental effects on the people and their environment (Soil, vegetation, water, air, agriculture, etc). In the same vein, the uncontrolled and carefree attitude with which the oil industries in Nigeria flare gas leave vast areas of the Niger Delta, particularly the oil bearing communities bare and impoverished. This adversely affects the entire wellbeing of the people living in the area. This theory of environmental externalities is relevant to this study because it is use as a construct to assess the impact of gas flaring on soil and cassava production.

\section{Methodology of Study}

Ebedei is one of the communities in Niger Delta region that is rich in gas and oil. Ebedei is under the local jurisdiction of Ukwuani Local Government Area of Delta State (Figure 2). Ukwuani Local Government Area is bounded to the North by Edo State, to the South and East by Ndokwa West and to the West Ethiope East, which is geographically located between latitude $5^{\circ} 51^{\prime} \mathrm{N}$ and $6^{\circ} 10^{\prime} \mathrm{N}$ and longitude $5^{\circ} 10^{\prime} \mathrm{E}$ and $5^{\circ} 48^{\prime} \mathrm{E}$ (insert). Ebedei lies within the Agbada, Akata and Benin Formation. The rocks are of sedimentary deposits having silt, clay and sand to top layer $(4-6 \mathrm{~m})$ and followed by coarse and pebbly (up to $17 \mathrm{~m}$ ) thick layer [55]. The area is characterized by hydromorphic soils, which is a mixture of coarse alluvial and colluvial deposits [55]. Thus, the soils are poorly drained and accumulated with water because it is near the Atlantic coast, having a high water table close to the surface. The Ase River and River Ethiope drains the area too.

Furthermore, its soil and low relief feature results in water stagnating on the ground surface with resistivity of water may vary from $0.20 \mathrm{Ohm}-\mathrm{m}$ to over $100.00 \mathrm{Ohm}-\mathrm{m}$ depending on its ionic concentration and the amount of dissolved solids [56]. The area is characterised by tropical equatorial climate with mean annual temperature of $27.32^{\circ} \mathrm{C}$, average relative humidity of about $60 \%-80 \%$ and annual rainfall amount of $4205 \mathrm{~mm}$ [57]. Generally, two major wind systems influence the climate of Ukwuani [56].

Both the experimental sites and control site were within the same climatic and soil zone, but the control site is not a gas flared area, so any observed differences as distance decay from flare sites could be attributed to the effect of the gas flaring. In all twelve (12) soil samples were collected from both the gas flared and non-flared area. These samples were then placed in labelled (A1-A5, B1-B5 and C1-C2) clean polythene bags and stored for analysis as was used by Ayodele, [58], Enahoro and Ehi-Ebewele, [59]. The collected soil samples were used to investigate 


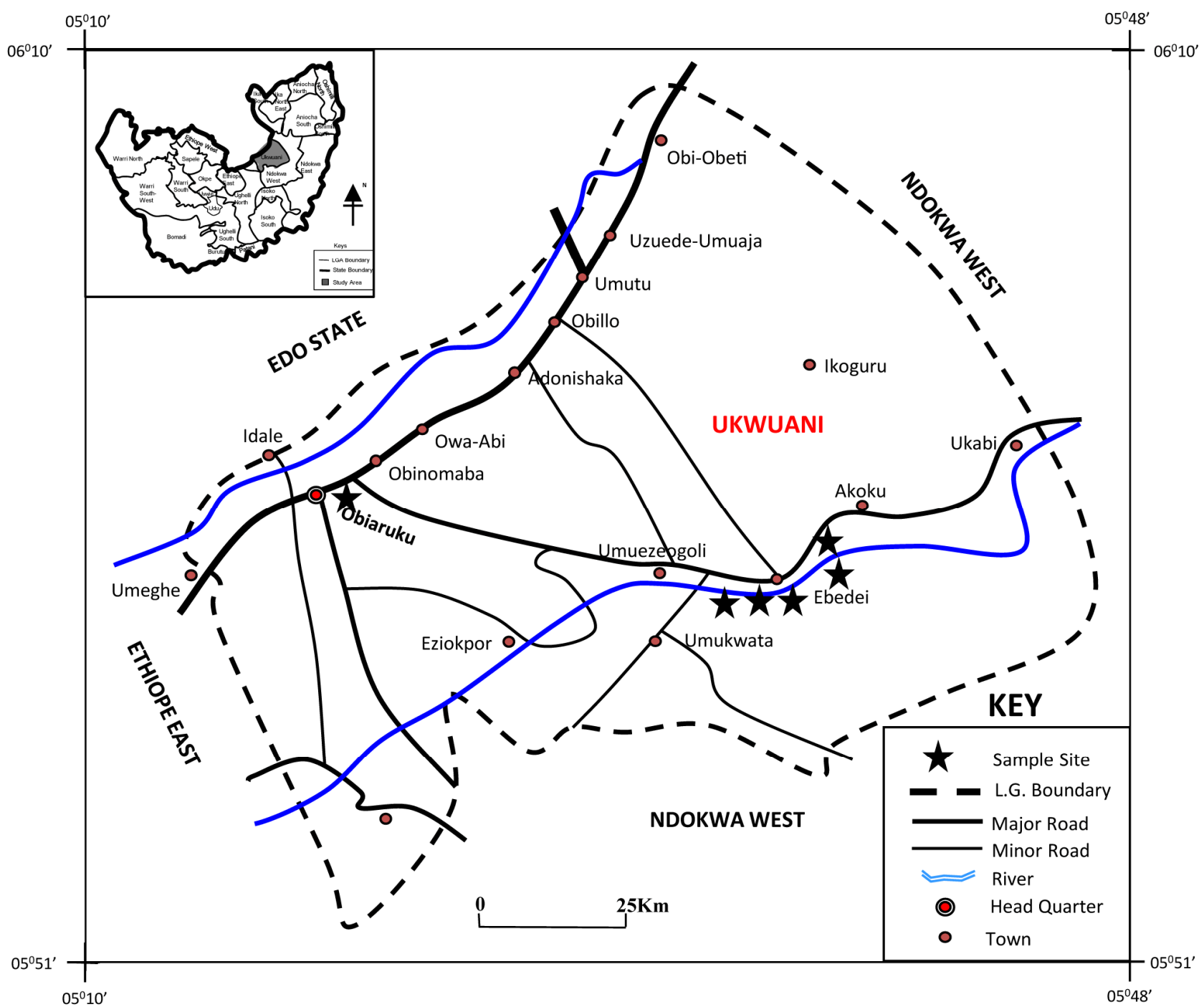

Source: Ministry of Lands, Surveys \& Urban Development, Asaba, (2004).

Figure 2. Map of Ukwuani showing sample Sites.

the soil $\mathrm{pH}$, organic carbon, EC, available phosphorous, total nitrogen etc.

Also as part of this study, cassava farm plots of $20 \mathrm{~m}$ by $20 \mathrm{~m}$ demarcated on farm plots were erected in each experimental site, making a total of six (6) farm site (50 $\mathrm{m}, 100 \mathrm{~m}, 150 \mathrm{~m}, 200 \mathrm{~m}, 250 \mathrm{~m}$ and the control). The ridges were dug manually using the spade and the giant African hoe. Each ridge having length of $4 \mathrm{~m}$ and eight (8) ridges of net plots were dug. On each plot, 21 cassava stems (20 - $25 \mathrm{~cm}$ long) were planted. The crops were planted on the same day after ridging was completed. An improved variety (TMS 30555) locally referred to as "Lagos" was planted. The selection of this variety of cassava among the numerous varieties available locally was because it is most valued and widely planted by the local farmers. Planting was done on the $2 / 4 / 2010$. No fertilizer was applied in this study. This is to enable us monitor clearly how gas flaring affect the physio-chemical status of the soil. With this, any notable difference in the soil nutrient could be attributed to gas flaring. Plants were harvested after one year and assessed for yield. The yield parameter taken includes the weight of harvested tuber/stand.

\subsection{Laboratory Analysis}

In a heterogeneous environment, such as soil, there are certain factors which give indication of the fertility of the soil. These include the particle size, organic carbon, total nitrogen, soil $\mathrm{pH}$, available phosphorus and cation exchange capacity, which give indication of a fertile soil [60]. Thus, these physical and chemical properties of the soil provide all the essential mineral elements of the soil, maintain soil fertility and the ability of the soil to hold and exchange cations. 
All the soil samples collected except for bulk density were air dried at room temperature, passed through a $2 \mathrm{~mm}$ sieve and analysed for; particle size composition by hydrometer method [61]; organic carbon by chromic acid digestion method of Walkley and Black [62]; total nitrogen by regular micro-kjedhl digestion method [63]; available phosphorus by Brays PI solution of Bray and Kurtz [64] and determined in accordance with Murphy and Riley [65] procedure; soil $\mathrm{pH}$ determined potentiometrically in distilled water using soil to water ratio of $1: 1$ [66]; cation exchange capacity value was determined by using ammonium acetate $\left(\mathrm{NH}_{4} \mathrm{OAC}\right)$ leachate method; and consecration of metals-lead, cadmium, nickel and chromium in the soil were determined by Atomic Absorption (AAS). These listed elements have been proved to be physiologically essential to plants growth, hence the effects of gas flares on these elements in determining the productivity of cassava at Ebedei. However, there is the need to determine the status of these elements in the laboratory in assessing the fertility level of the soil, visà-vis, the effect of gas flares on the soil fertility status. The soil particles size refers to the proportions of sand, silt and clay in the soil. It also refers to the ability of the soil to hold and respond to fertilizer application.

\subsection{Analysis/Statistical Technique}

In presenting the data, tables, statistical diagrams were employed. Subsequently, comparative analysis was made based on the data and presented on tables and statistical graphs. The data was analysed using the multiple regression and paired t-test.

\section{Findings and Discussion}

\subsection{Effects of Gas Flaring on Soil Nutrient}

Table 2 shows the physio-chemical properties of soils in
Ebedei and Obiaruku. The basic soil type ranges from $81.04 \%$ of sand, $3.45 \%$ of clay and $15.62 \%$ of silt in Ebedei, while the soil type in Obiaruku comprises $81.95 \%$ of sand, $4.78 \%$ of clay and $13.28 \%$ of silt. However, the soils indicate higher content of sand. This might be due to the effect of a nearby stream and land filling by relatively coarser materials.

Moreso, the soil temperature in the control site is lesser than that of the flared sites (Table 2). This is attributed to the heat radiation which is a function of the flare temperature, gas flow rate and geometrical design of flare stack [2]. Thus, soil temperature affects plant growth first during seed germination. The higher temperatures generated by the flare must have increased the evaporation rate [30].

Table 3 shows the chemical properties of soil in both the flared and non-flared site. The soil $\mathrm{pH}$ measures the level of soil acidity or alkalinity in a solution or substance. Thus, the soils found at Ebedei and Obiaruku are acidic. Alternatively, the observed slight acidity level of soils could have been responsible for the poor utilization of the nutrients in the growth medium [67].

More so, the organic carbon shows a range of $1.01 \%$ $2.10 \%$ with mean value of $1.78 \%$ in the flare site, and a range of $2.20 \%$ to $2.93 \%$ with mean value 2.57 in the control site. These values indicates that there is more organic carbon in soils where there is no gas flare and low

Table 2. Physical properties of soil in Ebedei and Obiaruku (control).

\begin{tabular}{ccc}
\hline Soil Parameters & Affected Area & Control Site \\
\hline Sand (\%) & 81.04 & 81.95 \\
Clay (\%) & 3.45 & 4.78 \\
Silt (\%) & 15.62 & 13.28 \\
Soil Temperature & 48.47 & 31.1 \\
\hline
\end{tabular}

Source: Field work, 2011.

Table 3. Chemical properties of Soil in Ebedei and Control Site (Obiaruku).

\begin{tabular}{|c|c|c|c|c|c|c|c|c|c|c|c|c|c|}
\hline \multirow{2}{*}{$\begin{array}{l}\text { No of } \\
\text { Point }\end{array}$} & \multirow{2}{*}{$\begin{array}{c}\text { Sample } \\
\text { Depth (cm) }\end{array}$} & \multirow{2}{*}{$\begin{array}{l}\text { Dist. From } \\
\text { Flare Site(m) }\end{array}$} & \multirow{2}{*}{$\begin{array}{c}\text { Soil pH } \\
\left(\text { in } \text { cacl }_{2}\right)\end{array}$} & \multirow{2}{*}{$\begin{array}{c}\text { Organic } \\
\text { carbon (\%) }\end{array}$} & \multirow{2}{*}{$\begin{array}{c}\text { EC } \\
(\mathrm{ms} / \mathrm{cm})\end{array}$} & \multirow{2}{*}{$\begin{array}{c}\text { Available } \\
\text { Phosphorous } \\
\text { (ppm) }\end{array}$} & \multirow{2}{*}{$\begin{array}{c}\text { Total } \\
\text { nitrogen } \\
(\%)\end{array}$} & \multicolumn{6}{|c|}{ Total Exchangeable cation (Meg/100g) } \\
\hline & & & & & & & & $\mathbf{K}^{+}$ & Meg & Ca & $\mathrm{Na}$ & CEC & EA \\
\hline \multirow{2}{*}{ A } & $0-10$ & 50 & 6.79 & 2.10 & 0.052 & 27.46 & 0.03 & 0.33 & 0.52 & 2.11 & 0.20 & 3.01 & 0.11 \\
\hline & $10-20$ & & 6.56 & 1.76 & 0.028 & 28.64 & 0.34 & 0.22 & 0.81 & 2.01 & 0.24 & 2.96 & 0.10 \\
\hline \multirow{2}{*}{$\mathrm{B}$} & $0-10$ & 100 & 6.23 & 1.90 & 0.032 & 29.22 & 0.46 & 0.13 & 0.83 & 2.22 & 0.42 & 4.72 & 0.12 \\
\hline & $10-20$ & & 5.97 & 1.71 & 0.023 & 28.89 & 0.20 & 0.57 & 0.52 & 2.43 & 0.19 & 5.17 & 0.10 \\
\hline \multirow{2}{*}{$\mathrm{C}$} & $0-10$ & 150 & 5.98 & 1.98 & 0.029 & 28.69 & 0.27 & 0.64 & 1.01 & 3.11 & 0.17 & 5.01 & 0.11 \\
\hline & $10-20$ & & 4.93 & 1.72 & 0.027 & 39.56 & 0.20 & 0.44 & 0.82 & 2.48 & 0.24 & 3.10 & 0.20 \\
\hline \multirow{2}{*}{ D } & $0-10$ & 200 & 6.20 & 2.04 & 0.025 & 32.45 & 0.18 & 0.31 & 0.79 & 2.51 & 0.19 & 3.96 & 0.64 \\
\hline & $10-20$ & & 5.49 & 1.71 & 0.020 & 31.66 & 0.14 & 0.29 & 0.51 & 1.46 & 0.20 & 2.01 & 0.60 \\
\hline \multirow{2}{*}{$\mathrm{E}$} & $0-10$ & 250 & 4.89 & 1.48 & 0.031 & 30.22 & 0.17 & 0.16 & 0.72 & 2.10 & 0.21 & 2.71 & 0.60 \\
\hline & $10-20$ & & 5.01 & 1.01 & 0.028 & 31.38 & 0.13 & 0.26 & 0.40 & 1.61 & 0.22 & 2.10 & 0.67 \\
\hline \multirow{2}{*}{ Control Site } & $0-10$ & & 6.38 & 0.93 & 1.89 & 37.20 & 2.00 & 0.20 & 3.01 & 2.78 & 2.41 & 5.11 & 1.12 \\
\hline & $10-20$ & & 5.24 & 2.20 & 1.22 & 32.39 & 2.11 & 1.85 & 2.83 & 4.01 & 1.67 & 3.20 & 1.91 \\
\hline
\end{tabular}

Source: Field Work, 2011. 
organic carbon in the soil that is affected by gas flare (see Figure 3). Odjugo [68] posited organic carbon content decreases towards flare site.

The Electrical conductivity shows the value of electrical conductivity in the soil ranges from 0.020 to 0.052 $\mathrm{ms} / \mathrm{cm}$ with mean value of $0.052 \mathrm{~ms} / \mathrm{cm}$ in the flared site, while the value is very low compare to the control site which the value ranges from 1.22 to $1.89 \mathrm{~ms} / \mathrm{cm}$ with mean value of $1.56 \mathrm{~ms} / \mathrm{cm}$ (see Figure 4). This implies that the EC in the gas flared site is greater than that of the non-flared site [68].

The phosphorous values ranges from $27.46 \mathrm{ppm}$ to $31.38 \mathrm{ppm}$ with mean value of $29.81 \mathrm{ppm}$, which is lower in comparison with the value of the control site that ranges from $32.39 \mathrm{ppm}$ to $37.20 \mathrm{ppm}$ with mean value of $34.80 \mathrm{ppm}$ that is higher. Moreso, the value of the total Nitrogen in Ebedei soil is above the range of $0.03 \%$ to $0.46 \%$ with mean value of $0.21 \%$. Thus, indicating that the total nitrogen in the soil is low compare to the control site which is higher with the range of $2.00 \%$ to $2.11 \%$ with mean value of $2.06 \%$ (see Figure 5).

Potassium value ranges from 0.13 to $0.64 \mathrm{Mq} / 100 \mathrm{~g}$ with mean value of $0.34 \mathrm{meq} / 100 \mathrm{~g}$, magnesium ranges between 0.40 to $1.01 \mathrm{meq} / 100 \mathrm{~g}$ with mean value of 0.69 meq $/ 100 \mathrm{~g}$, calcium ranges between 1.46 to $3.11 \mathrm{meq} / 100 \mathrm{~g}$ with mean value of $2.20 \mathrm{meq} / 100 \mathrm{~g}$ and sodium ranges from between 0.17 to $0.42 \mathrm{meq} / 100 \mathrm{~g}$ with mean value of 0.23 (see Table 3). These values are low with sodium having the lowest value and high in calcium having the highest value. This is an implication that the result of the physio-chemical properties of the soil is a clear indication that the excessive heat generated by the flare did not only modify the microclimate but also the soil nutrient [68].

\section{organic Carbon}

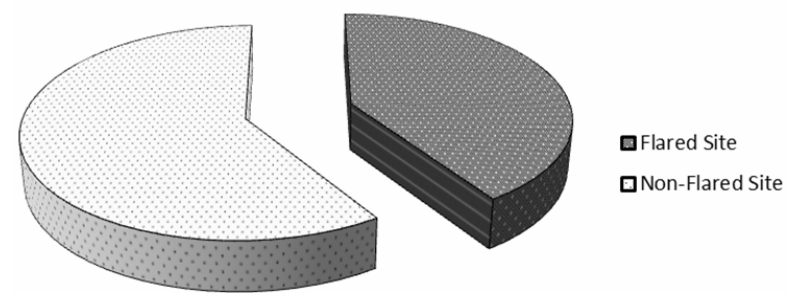

Figure 3. Organic carbon.

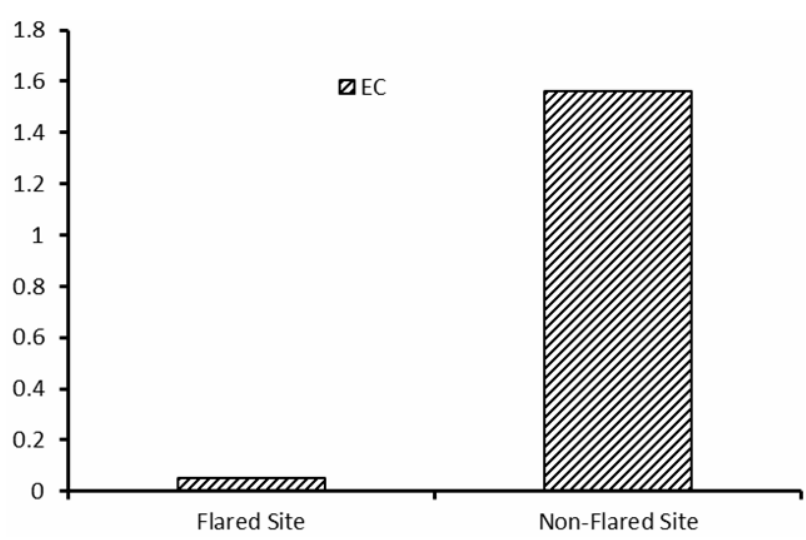

Figure 4. Electrical conductivity

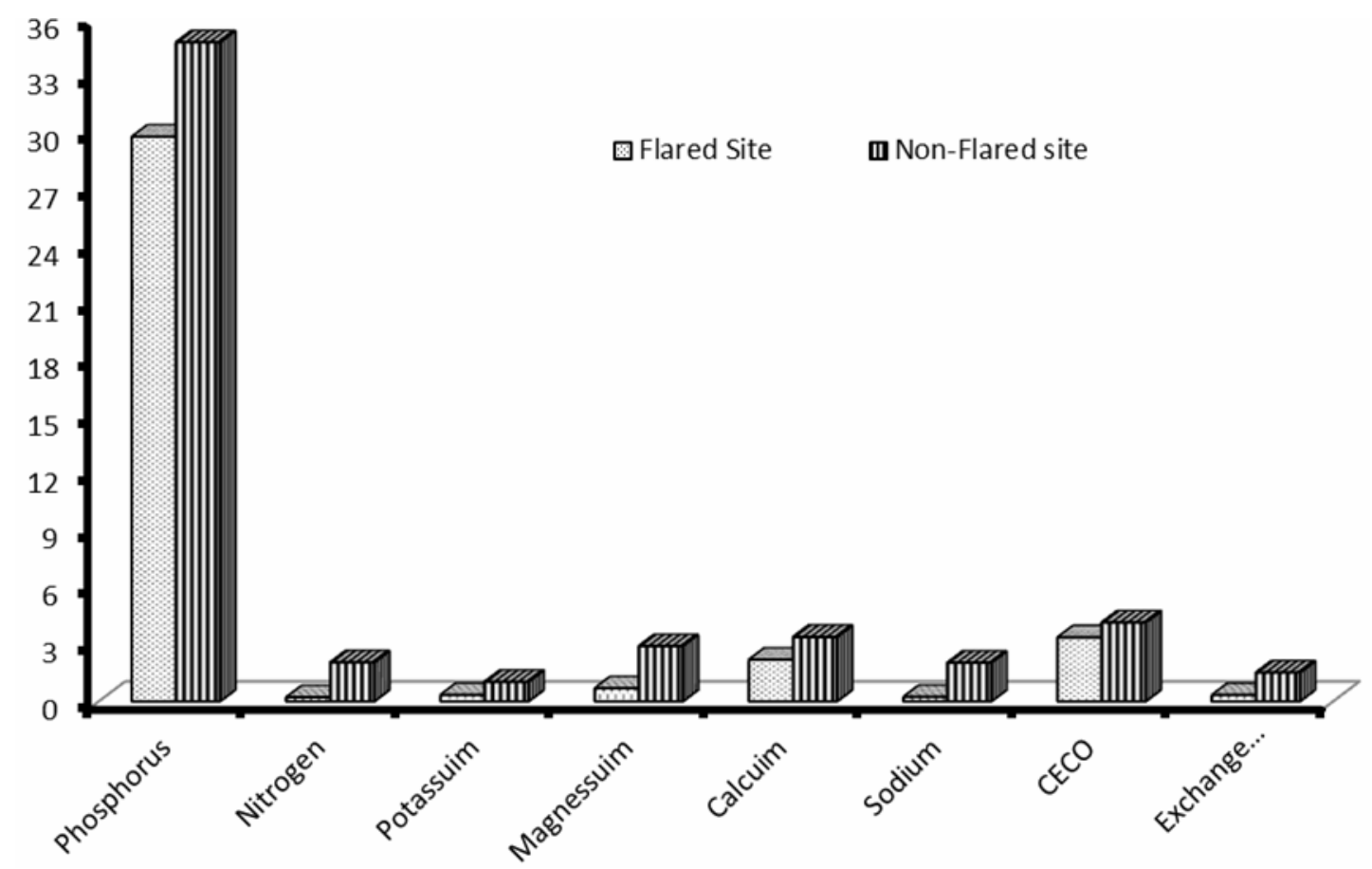

Figure 5. Chemical properties of the soils. 


\subsection{Hypothesis One}

The hypothesis states that there is no significant variation in soil nutrient as distance increases from gas flare sites.

Table 4 revealed that there is a correlation of 0.997 between gas flare distance and physio-chemical properties of soil, which indicate $r^{2}$ value of 0.995 . This implies that $99.5 \%$ of physio-chemical properties of soil were attributed to the distance of gas flare site in Ebedei. At $\mathrm{P}$ $<0.05$, the calculated $F$ value is 234.99 while the critical table value is 4.39 . Since calculated value is greater than critical value the null hypothesis is rejected and the alternative hypothesis which states that there is significant difference between flare distance and the soil nutrient is accepted. Gas flaring has been reported by many researchers to be a major cause of low agricultural production [27-30].

Furthermore, from the standardized coefficient values in Table 5, the beta value shows a positive correlation for organic carbon, electrical conductivity, Nitrogen. Thus, indicating that as flare distance increases, the organic carbon, electrical conductivity, Nitrogen also increases.

\subsection{Cassava Yield}

Table 6 shows the yield of cassava as associated to the varying distance. It was observed that cassava yield in- creases with a corresponding increase in distances from flare site. This is an implication that the reduction of cassava yield close to the flare site was as a result of gas flaring which has affected the soils (Figure 6). This corroborated the view of Udoinyang [31], Akpabio [32] and Odjugo [30] who earlier observed that gas flaring reduces the growth and yield of plantain and root crops as a result of depletion in soil fertility in the Niger Delta region of Nigeria.

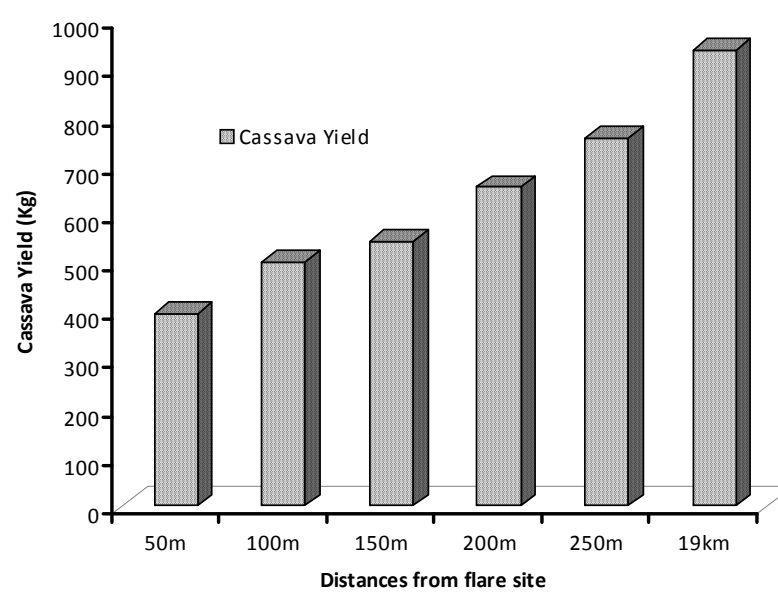

Figure 6. Cassava yield from the varying distance of flare sites.

Table 4. Coefficient explaining the relationship between soil nutrient and increased gas flare distance.

\begin{tabular}{|c|c|c|c|c|c|c|c|c|c|}
\hline \multirow[b]{3}{*}{ Model } & \multirow[b]{3}{*}{$\mathrm{R}$} & \multirow[b]{3}{*}{ R Square } & \multirow[b]{3}{*}{ Adjusted R Square } & \multirow[b]{3}{*}{ Std. Error of the Estimate } & \multirow{2}{*}{\multicolumn{5}{|c|}{ Change Statistics }} \\
\hline & & & & & & & & & \\
\hline & & & & & R Square Change & F Change & df1 & $\mathrm{df} 2$ & Sig. F Change \\
\hline 1 & $0.997^{\mathrm{a}}$ & 0.995 & 0.991 & 1722.442 & 0.995 & 234.997 & 5 & 6 & 0.000 \\
\hline
\end{tabular}

apredictors: (Constant), Nitrogen, Soil_pH, Organic_carbon, Phosphorous, EC.

Table 5. Standardize beta coefficient.

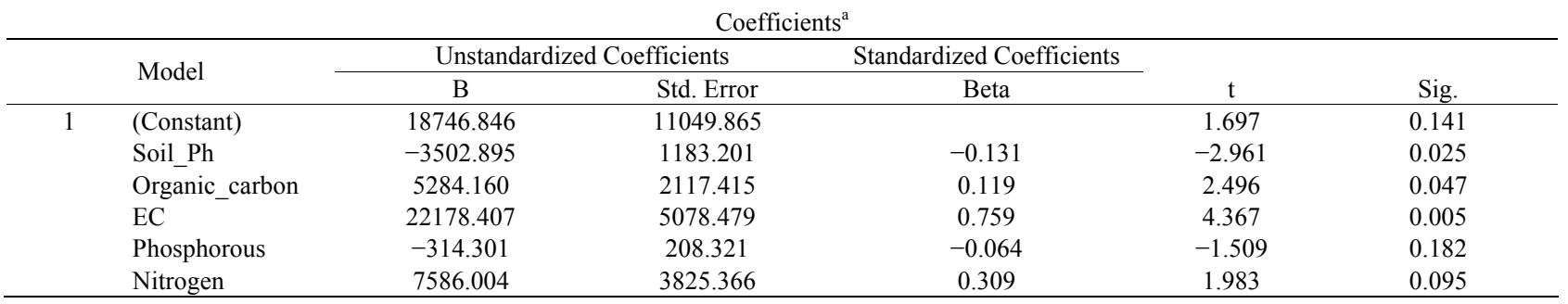

${ }^{\mathrm{a}}$ Dependent Variable: Flare_Distance.

Table 6. Cassava yield and distances from the flare site.

\begin{tabular}{|c|c|c|c|c|c|c|c|c|}
\hline \multirow[b]{3}{*}{ Distances (m) } & \multicolumn{8}{|c|}{ Yield of Cassava in Kg } \\
\hline & \multicolumn{8}{|c|}{ Ridges } \\
\hline & $\mathrm{A}$ & $\mathrm{B}$ & $\mathrm{C}$ & $\mathrm{D}$ & $\mathrm{E}$ & $\mathrm{F}$ & G & $\mathrm{H}$ \\
\hline 50 & 41 & 39 & 59 & 54 & 56 & 64 & 43 & 40 \\
\hline 100 & 59 & 54 & 67 & 66 & 68 & 70 & 60 & 57 \\
\hline 150 & 66 & 60 & 72 & 69 & 71 & 73 & 68 & 65 \\
\hline 200 & 78 & 72 & 88 & 85 & 87 & 90 & 79 & 77 \\
\hline 250 & 91 & 89 & 100 & 95 & 99 & 101 & 92 & 91 \\
\hline
\end{tabular}

Source: Field work, 2011. 


\section{Test of Hypothesis Two}

The hypothesis two states that there is no significant difference in cassava yield at gas flared area and the nonflared area.

From Table 7, Mean cassava yield in the non-flared area was $117.38(\mathrm{SD}=7.82)$ and the mean cassava yield in the flared site was $94.75(\mathrm{SD}=4.68)$, indicating that cassava yield reduces after the impact of gas flared.

From Table 8 the calculated $t$ value is 6.032 while the critical $\mathrm{t}$ table value is 1.895 at $\mathrm{P}<0.05$. Since calculated $\mathrm{t}$ value is greater than critical (table) $\mathrm{t}$ value, $\mathrm{H}_{0}$ (null Hypothesis) is rejected and $\mathrm{H}_{1}$ (alternative Hypothesis) is accepted. Thus, there significant difference in cassava yield at gas flared area and the non-flared area. This finding corroborates with the works of Odjugo [30].

The following are the major findings;

1) The soils found in Ebedei have high composition of sand. This might be due to the effect of a nearby stream and land filling by relatively coarser soil.

2) Soil temperature in Ebedei is high which might be attributed to the heat radiation which is a function of the flare temperature, gas flow rate and geometrical design of flare stack. Thus, soil temperature affects plant growth first during seed germination. The higher temperatures generated by the flare must have increased the evaporation rate.

3) The soils found at Ebedei are acidic and contains high amount of carbon which is attributed to the flaring. Alternatively, the observed slight acidity level of soils could have been responsible for the poor utilization of the nutrients in the growth medium.

4) The soil electrical conductivity, phosphorous, Nitrogen, Potassium and Sodium are very low.

5) The yield of cassava increases with a corresponding increase in distances from flare site. Thus implying that the reduction of cassava yield close to the flare site was as a result of gas flaring which has affected the soils.

6) The first hypothesis revealed that there is significantly relationship between physio-chemical properties of soil and the distance of flaring. This is evident from $\mathrm{F}$ value of 234.99 which is greater than the critical table value of 4.39. Furthermore, as flare distance increases, so also the organic carbon, electrical conductivity and Nitrogen increase. The second hypothesis revealed that there is a significant difference in cassava yield at the gas-flared area and the non-flared area which is evident at $\mathrm{t}(6.032)$ is greater than the critical table (1.895) at $\mathrm{P}<$ 0.05 .

\section{Recommendations}

In the light of the above findings, the following recommendations were made with respect to the impact of gas flaring on soil and cassava productivity:

1) The greatest recommendation is that Federal Government through the Federal Ministry of Environmental Protection Agency (FEPA), Niger Delta Affairs Ministry, Policy Makers and stakeholders in environment and oil sector should revisit and review existing environmental and oil drilling laws in Nigeria with a view of updating them to international and environmental friendly standards. Strict implementation of oil drilling related laws by the government and appropriate bodies with elimination of corruption and bureaucratic bottleneck is recommended. There should also be a modification in the current regulatory framework of gas flaring and holistic approach to the environment of planning, development and management of land resources.

2) The Federal Government policy on zero flare by July, 2008 should be put to place and not a mere policy statement. This could be done by the utilization of the gas being flared through re-injection process during oil production, and construction of gas plants for electricity generation and harness the flared gas for both private and commercial uses.

3) There should be appropriate compensation by the multinational oil companies to the bearing communities, also to see to their socio-economic well-being. All the equipment used by the oil companies should be up dated

Table 7. Paired samples statistic.

\begin{tabular}{clcccc}
\hline & Mean & N & Std. Deviation & Std. Error Mean \\
\hline Pair & Non_flared_Area & 117.3750 & 8 & 7.81825 & 2.76417 \\
1 & Flared_area & 94.7500 & 8 & 4.68280 & 1.65562 \\
\hline
\end{tabular}

Table 8. Paired sample test.

\begin{tabular}{|c|c|c|c|c|c|c|c|c|}
\hline \multicolumn{9}{|c|}{ Paired Differences } \\
\hline & \multirow{2}{*}{ Mean } & \multirow{2}{*}{ Std. Deviation } & \multirow{2}{*}{ Std. Error Mean } & \multicolumn{2}{|c|}{$95 \%$ Confidence Interval of the Difference } & \multirow[b]{2}{*}{$\mathrm{t}$} & \multirow[b]{2}{*}{ df } & \multirow[b]{2}{*}{ Sig. (2-tailed) } \\
\hline & & & & Lower & Upper & & & \\
\hline $\begin{array}{cl}\text { Pair } & \text { Non_flared_Area } \\
1 & \text { Flared_area }\end{array}$ & 22.62500 & 10.60913 & 3.75089 & 13.75555 & 31.49445 & 6.032 & 7 & 0.001 \\
\hline
\end{tabular}


and modernized to international standards. Thus, a technology that will enable complete combustion of the gases is important. This will reduce the production and decomposition of some nitrogen oxides, carbon, sulphur and soot oxides.

4) There should be a constant environmental monitoring, assessment and evaluation to determine the level of damage that is done by gas flaring and other oil pollutions on the environment as a whole.

5) The companies and government should provide relief assistance to the bearing communities as regards to the provision of basic input such as fertilizers to the various farmers as to enable them to produce enough food crops as their only mainstay of livelihood and compensation should be paid to host communities. The Federal Government should ensure that all decisions relating to environmental quality integrate the need for sustainable development for future generation.

6) Finally, gas flaring activities in the country should be abolished in order to improve the life expectancy and standard living of the populace.

\section{Conclusion}

This research was undertaken to examine the impact of gas flaring on soil and cassava productivity in Ebedei. From the study, it is seen that gas flaring has untold effects in the environment especially in the area of study, which ranges from its effect on the soil to its effect in the entire environment. Apart from affecting the chemical properties of the soil, it also resulted to poor soil fertility or nutrient, leading to poor crop productivity in the area. However, it is worthy to note that gas flaring affects agricultural and economic activities of oil host communities in Nigeria. Therefore, both the government and the oil companies should keep up to the challenges of monitoring, evaluating and managing the oil drilling environment for a sustainable environmental development.

\section{REFERENCES}

[1] L. A. Nwaogu and G. O. C. Onyeze, "Environmental Impact of Gas Flaring on Ebocha-Egbema, Niger Delta," Nigerian Journal of Biochemistry and Molecular Biology, Vol. 25, No. 1, 2010, pp. 25-30.

[2] A. S. Abdulkareem, "Evaluation of Ground Level Concentration of Pollutant Due to Gas Flaring by Computer Simulation: A Case Study of Niger-Delta Area of Nigeria," Leonardo Electronic Journal of Practices and Technologies, Vol. 6, No. 1, 2005, pp. 29-42.

[3] N. J. Ikoro, "The Socio-Economic Implications of Gas flaring in Nigeria," Du-France Communications, Yenegoa, 2003.

[4] B. Guven, R. Hariss and D. Hertzmark, "Gas Flaring and Venting: Extent, Impact, and Remedies," James Baker Institute of Public Policy, Rice University, 2010, p. 73.
[5] S. Yakubu, "Gas Flaring in the Niger Delta and Its Health Hazards," 2008.

http://allafrica.com/stories/200803100319.html

[6] B. S. V. Atevure, "Processes of Oil Production and Environmental Degradation: An Overview," Journal of Environmental Analysis, Vol. 2, No. 1, 2004, pp. 76-85.

[7] O. E. Inyang, "Gas Flaring and the Nigerian Economy," Economic Review, Vol. 14, No. 1, 2007, pp. 25-33.

[8] N. V. Okoh, "Environmental Impacts of Oil Exploration," Atmospheric Review, Vol. 12, No. 1, 2000, pp. 68-80.

[9] C. J. Obi, "The Oil Sector and Sustainable Environment," Environmental Knowledge, Vol. 13, No. 1, 2001, pp. 1-18.

[10] P. A. O. Odjugo, "The Impact of Gas Flaring on Atmospheric Quality: The Case of Niger-Delta, Nigeria," International Journal of Ecology, Evolution and Dynamics, Vol. 2, No. 1, 2004, pp. 12-33.

[11] P. A. O. Odjugo, "Health, Safety and Environment: Challenges of the Environmental Health Officers in the Present Democratic Dispensation," The 3rd Delta State Triennial Delegates Conference, Asaba, 13-15 June 2002, pp. 4-8.

[12] M. Strosher, "Investigation of Flare Gas Emission in Alberta," Environmental Technologies, Alberta Research Council Report, 1996, p. 7.

[13] J. Haberern, "View Point: A Soil Health Index," Journal of Soil and Water Conservation, Vol. 47, No. 1, 1992, p. 6.

[14] B. L. Turner, R. E. Kerperson, W. B. Meyer, K. M. Dow, D. Golding, R. C. Mitchell and S. J. Ratick, "Two Types of Global Environmental Changes: Definition of Spatial Scale Issues in Their Human Dimensions," Global Environmental Change, Vol. 1, No. 1, 1990, pp. 14-22. http://dx.doi.org/10.1016/0959-3780(90)90004-S

[15] I. J. Alakpodia, "The Effects of Gas Flaring on the MicroClimate and Adjacent Vegetation in Isoko Area of Bendel State," Unpublished M.Sc. Thesis, University of Ibadan, 1989.

[16] S. A. Okecha, "Pollution and Conservation of Nigeria's Environment," T'Afrique International Association (W.A.) Ebenezer Court, Owerri, 2000, pp. 16-18, 36.

[17] World Bank, "Defining an Environmental Development Strategy for Niger Delta," West Africa Department, World Bank, Washington DC, 1995.

[18] B. Svensson, "Gas Flaring Waster Resources, Pollutes Atmosphere," 2007 GM Watch. www.environmnetal/news/network

[19] Gbadegesin, "The Impact of Oil Exploitation and Production Activities on the Environment: Implication for Peasant Agriculture," Seminar Paper on Oil and the Environment by Fredrick Ebert Foundations, Port Harcourt, 1997.

[20] Shell Petroleum Development Company, "Discharges to Land and Water," Emission to Air in People and the Environment Annual Report, Warri, 1996, pp. 14-16.

[21] Shell Petroleum Development Company, "Annual Repot 'HSE Performance Summary'," 2003, p. 23.

[22] Nigeria Environmental Study/Action Team [NEST], "Nigeria Threatened Environment," A National Profile, Iba- 
Effect of Gas Flaring on Soil and Cassava Productivity in Ebedei, Ukwuani Local Government Area, Delta State, Nigeria 1065

dan, 1991, pp. 44-47.

[23] D. V. Okizie, "Gas Flaring of Associated Gas in Oil Industry Impact on Productivity of Crops," The Izombe Flow Station Workshop, 1989.

[24] A. Faniran and O. Areola, "Essentials of Soil Studies with Special Reference to Tropical Area," Heinemann, London, 1985.

[25] United Nations Development Programme [UNDP], "Strategic Gas Plan for Nigeria," 2004.

[26] I. J. Alakpodia, "Soil Characteristics under Gas Flare in Niger Delta, Southern Nigeria," Geo-Studies Forum, An International Journal of Environmental and Policy Issues, Vol. 1, No. 2, 2000, pp. 1-10.

[27] O. D. Daudu, "Socio-Economic and Environmental Problems Associated with Oil Spillage in the Niger Delta," Unpublished M.Sc. Dissertation, Department of Environmental Sciences, Imo State University, Owerri, 2001.

[28] B. O. Aregbeyen and B. W. Adeoye, "The Oil Industry, Environmental Health and Sustainable Development in Nigeria," African Journal of Environmental Studies, Vol. 2, No. 1, 2001, pp. 8-14.

[29] P. A. O. Odjugo, "Some Effects of Gas Flaring on the Microclimate of Yam and Cassava Production in Erhorike and Environs. Delta State, Nigeria," Nigerian Geograhical Journal, Vol. 5, No. 1, 2007, pp. 43-54.

[30] G. U. Udoinyang, "The Effects of Gas Flaring on Sweet Potato Production in the Niger Delta, Nigeria," Journal of Ecosystem, Vol. 10, No. 1, 2005, pp. 77-86.

[31] Z. K. A. Akpabio, "The Impacts of Gas Flaring on Microenvironment and Yield of Plantain in Rivers State, Nigeria," Environmental Perspectives, Vol. 10, No. 1, 2006, pp. 1-11.

[32] O. O. Ikelegbe, "Pollution in Nigeria, Cause Effect and Control," 20th Proceedings of Nigeria Geographical Association Conference, Minna, 20-24 November 1993, pp. 17-18.

[33] G. O. Onosode, "Keynote Address," Presented at International Seminar on Petroleum Industry and the Nigeria Environment, Harcourt, 1996.

[34] Y. Sawaragi and H. Akashi, "Environmental System Planning Design and Control," Pergamon Press, New York, 1978, pp. 31-32.

[35] J. H. Thomas and P. J. Allen, "CNN Weather Report," 1999, p. 3.

[36] J. E. Penner, "Aviation and Global Atmosphere, Inter Governmental Parley on Climate Change," Cambridge University Press, Cambridge, 1999.

[37] Central Bank of Nigeria, Publication, 1995.

[38] O. Linden and D. Moffat, "Perception and Reality: Assessing Priorities for Sustainable Development in Niger Delta," Ambio: A Journal of the Human Environment, Vol. 24, No. 7-8, 1995, pp. 527-538.

[39] T. Hunt, "The Politics of Bone," 2000. http:/mebers.home.net/jti-mthy/wiwa.htm

[40] C. C. Achebe and P. R. Epstein, "Oil Prize or Curse?" 2004, pp. 1-10. http://www.ued.ie/dipeon/dou/theme02/theme02-07.pdf
[41] R. Abiodun, "Nigeria Oil Worker and Families Rage against Foreign Companies," Ectopic International News Serving, 2004

[42] D. O. Egbuna, "The Environmental Hazards of the Nigerian Gas Industry, in Petroleum Industry and the Nigerian Environment," Proceedings of 1987 Seminar, Lagos, 1987, pp. 3-5.

[43] A. Ogidiolu, "Effects of Gas Flaring on Soil and Vegetation Characteristics in Oil Producing Region of Niger Delta Nigeria," International Journal of Ecology and Environmental Dynamics, Vol. 1, No. 1, 2003, pp. 47-53.

[44] P. A. Sanchez, "Properties and Mismanagement of Soil in the Tropics," John Wiley and Sons, New York, 1976.

[45] G. Finnveden and T. Ekvall, "Life-Cycle Assessment as a Derision Support Tool-The Case of Recycling Versus Incineration of Paper," Resources, Conservation and Recycling, Vol. 24, No. 3-4, 1998, pp. 235-356. http://dx.doi.org/10.1016/S0921-3449(98)00039-1

[46] P. O. Sada, "Development and the Environment: A Conceptual Framework for Environmental Management," In: P. O. Sada and F. O. Odemerho, Eds., Environmental Issues and Management in Nigerian Development, Evans Brothers (Nigeria Publisher) Limited, Ibadan, 1988, pp. 27-37.

[47] A. C. Pigou, "The Economics of Welfare," Macmillan, London, 1920.

[48] M. A. Iyoha, "The Environmental Effect of Oil Industry Activities on the Nigerian Economy. A Theoretical Analysis," In: C. O. Orubu, D. O. Ogisi and R. N. Okoh, Eds., The Petroleum Industry, the Economy and the Niger Delta Environment, Jayco Press, Ovwian Warri, 2002, pp. 4-16.

[49] W. J. Baumol and W. E. Oates, "The Theory of Environmental Policy," 2nd Edition, Cambridge University Press, Cambridge, 1988. http://dx.doi.org/10.1017/CBO9781139173513

[50] D. Helm and D. Pearce, "Economic Policy towards the Environment: An Overview," In: D. Helm, Ed., Economic Policy towards the Environment, Oxford Blackwell Publishers, Oxford, 1991, p. 2.

[51] N. O. Schouten and A. J. O'Sullivian, "Monitoring and Evaluation of Oil Related Population in NNPC Operation," Proceeding of the Seminar on Petroleum Industry and Nigeria Government, Owerri, 1987, pp. 5-8.

[52] J. O. Oseji, "Near Surface Aquifer Characteristics and Groundwater Potential in Onicha-Ukwuani, Delta State, Nigeria," The Pacific Journal of Science and Technology, Vol. 10, No. 2, 2009, pp. 633-642.

[53] C. Okuoyibo, "The Effect of Transportation Network on Rural Development in Ukwuani Local Government Area of Delta State," Unpublished B.Sc Project, Delta State University, Abraka, 2006.

[54] F. A. Ayodele, "Ecological Basis for the Management of Oyo National Park," Unpublished Ph.D. Thesis of University of Ibadan, Ibadan, 1988.

[55] J. A. Enahoro and E. E. O. Ehi-Ebewele, "Effect of the Oil Industry on the Enviroment: Shift in Paradigm on Financial Reporting Disclosure for Sustainable Enviromen- 
1066 Effect of Gas Flaring on Soil and Cassava Productivity in Ebedei, Ukwuani Local Government Area, Delta State, Nigeria

tal Development," The Conference Proceedings of the International Conference on the Nigeria State, Oil Industry and the Niger Delta, Yenagoa, 11-13 March 2008, pp. 604-632.

[56] E. A, Aduayi, "Making the Soil Nutritious to Plant," Inaugural Lecture Series, Obafemi Awolowo University press Ltd, Ile Ife, 1985.

[57] O. M. Agbogidi, P. G. Eruotor and S. O. Akparobi, "Ef- fects of Crude Oil Levels on the Growth of Maize (Zea mays L.)," American Journal of Food Technology, Vol. 2, No. 6, 2007, pp. 529-535.

http://dx.doi.org/10.3923/ajft.2007.529.535

[58] P. A. O. Odjugo, "General Overview of Climate Change Impacts in Nigeria," Journal of Human Ecology, Vol. 29, No. 1, 2010, pp. 47-55. 